\title{
The Judicial Use of DNA Evidence and Forensic Expert Testimony in the Criminal Justice System
}

Richard S. Gunasekera*, Jennifer Haschke and Elliott H. Costas J.D.

Department of Biology, School of Arts \& Sciences, University of Houston-Victoria, University of Houston System in Sugar Land, 14,000 University Blvd, Sugar Land, TX 77479, USA

\begin{abstract}
In the forensic sciences, DNA analysis is especially useful in sexual assault cases where body contact is made or bodily fluids are exchanged. However, its usefulness can be severely limited within the contour of the criminal justice system. This article discusses a case wherein short tandem repeat DNA typing was used to charge the defendant with sexual assault of a child. The State's DNA technicians analyzed the victim's underclothing and reviewed the victim's sexual assault nurse examination (SANE). Our independent review of the State's forensic laboratory work showed that the samples used to obtain a DNA match from the victim's underclothing and the defendant revealed a third contributor. An allele was found that did not match either the victim or the defendant as shown by us as expert witness. A ruling by the trial judge limited what the jury was allowed to hear regarding our findings. The defendant was found guilty. The defendant appealed the guilty verdict based on the trial judge's decision to limit defense expert witness testimony. Following established law, the appellate court upheld the conviction, ruling that a victim's testimony alone, with or without any corroborating forensic evidence, supports a finding of guilt.
\end{abstract}

Keywords: DNA; Genetic analyzer; Allele; Loci; Short Tandem Repeat (STR); RFU; Trial court; Appellate court; Sexual assault; Genemapper ID; Electropherogram; CODIS

\section{Introduction}

The addition of DNA analysis to the quiver of forensic techniques has transformed the field of forensic science from what was once an art in sleuthing to one that increasingly embraces the scientific method. Professional scientific societies, however, still consider forensic science an "emerging science". This is primarily because the unbiased objectivity deemed by the scientific method cannot always be implemented in the contours of the criminal justice system. Until DNA was used for identification purposes, blood typing was the closest method for matching human subjects with bodily fluids left behind at a crime scene. Identification by blood type is less significant when compared to DNA in relation to specificity because there are only four main types of blood in human populations. Thus, there have been many noted false convictions based upon blood typing. In comparison, DNA typing provides a greater statistically significant match from acceptable bodily samples between suspect(s) and $\operatorname{victim}(\mathrm{s})$.

Today, the most widely used DNA typing method for forensic cases are short tandem repeat (STR) analysis utilizing an automated

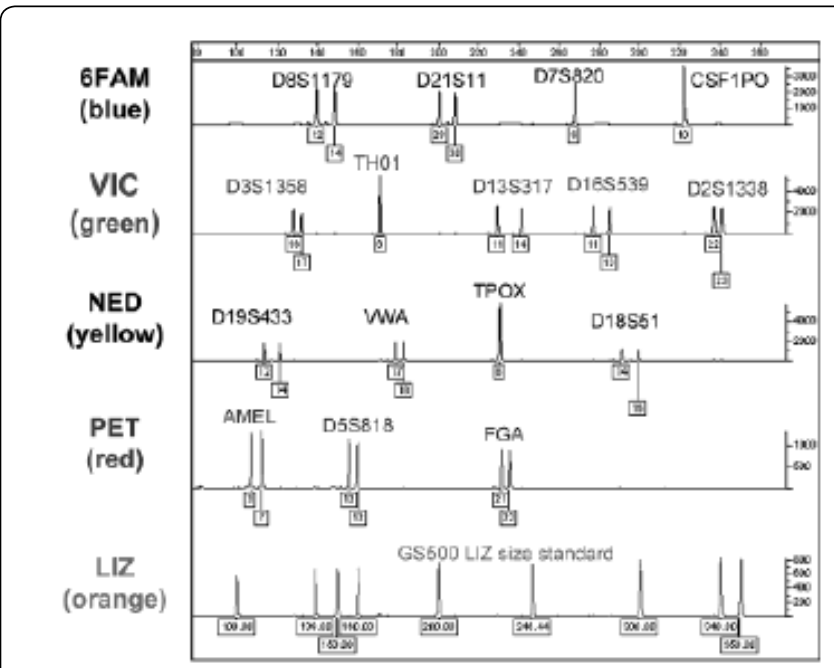

Figure 1: Example Electropherogram from Genetic Analyzer ABI 310.
DNA Sequencer or Genetic Analyzer. STRs are short fragments of repetitive DNA, approximately 6-9 nucleotides in length, found dispersed throughout non-coding regions of the human genome. In the mid nineteen nineties the US FBI laboratory conducted a national forensic science effort to evaluate17 candidate STR loci (plural for locus, a position on a chromosome) with the intention of including these in the DNA database known as CODIS (Combined DNA Index System). The objective of this evaluation was to utilize them for identification purposes by STR analysis. For each locus a person can have two alleles, one inherited from each parent. Sometimes, a person may receive the same allele from both parents, and at such times only one allele will be seen on the electropherogram because of a shared DNA marker. The STR analysis pinpoints where these alleles are typed for each individual at specific loci to make up a DNA profile for each sample. Unknown samples can then be compared to the known sample at their respective loci. For a match, each of the two alleles for the unknown individual should match identically to the sample obtained from the control (known sample) in their position in an electropherogram (Figure 1). The DNA profile will be the same if it is originating from the same individual. The only exception to this case would be if the two samples, known and unknown were to originate from identical twins.

Originally thirteen core STR loci were chosen to be the basis of the CODIS database [1]. When all 13 loci are tested, the average random match probability is rarer than one in a trillion among unrelated individuals [2]. However, even though the admissibility and reliability of the tests have been well established, there is no guarantee that a specific test will have the reproducibility results every time. There are often case specific problems and issues. These greatly affect the

*Corresponding author: Richard S. Gunasekera, PhD , Professor of Biology, Director of Graduate Studies, University of Houston-Victoria, University of Houston System in Sugar Land, 14,000 University Blvd. Sugar Land, TX 77479, Tel: (281) 275-8826; Fax: (281) 275-3361; E-mail: GunasekeraR@uhv.edu

Received December 09, 2010; Accepted December 28, 2010; Published December 29, 2010

Citation: Gunasekera RS, Haschke J, Costas EH (2010) The Judicial Use of DNA Evidence and Forensic Expert Testimony in the Criminal Justice System. Forensic Res 1:104. doi:10.4172/2157-7145.1000104

Copyright: (C) 2010 Gunasekera RS, et al. This is an open-access article distributed under the terms of the Creative Commons Attribution License, which permits unrestricted use, distribution, and reproduction in any medium, provided the original author and source are credited. 
quality and the relevance of DNA tests results. According to William C. Thompson, J.D., Ph.D, "The criminal justice system does a poor job distinguishing powerful DNA evidence from weak, misleading DNA evidence. The fault for that serious lapse lies partly with those defense lawyers who fail to evaluate the DNA evidence adequately in their cases [3].

The DNA gathered from a crime scene or a crime victim must meet certain criteria to be admissible in court. The salient criteria pertain to: sample collection, sample storage (such that DNA samples are kept from deterioration), maintenance of a chain of custody among law enforcement officers and laboratory technicians, analysis in the laboratory setting according to accredited protocols and procedures, and correct interpretation of results [4]. Experts for the State and the defense in a criminal case review adherence to the above criteria, with emphasis on DNA laboratory findings, and present expert testimony supporting or controverting such findings. Pursuant to legal precedent the trial court exercises a gate keeping function regarding the admissibility of expert testimony and other evidence at trial. Ultimately, however, the legal system defers to the decision of the ultimate finders of fact, the jury.

\section{Case Report}

In the subject case, a twelve year old female alleged that she had been sexually assaulted through vaginal sexual intercourse. The assault was initially reported to law enforcement within fifteen hours of its alleged occurrence, followed by a sexual assault nurse examination (SANE) some 48 hours after the event. SANE protocol includes physical examination of the victim, collecting bodily samples using a sexual assault evidence kit, and collecting other potential evidence, as dictated by case circumstances. The primary defensive issues that could create the reasonable doubt substantiating the reasonable doubt for acquittal at Defendant's jury trial were (1) the SANE examination did not occur until more than 48 hours after the alleged assault and (2) the possibility of a third contributor of DNA in the samples extracted from the victim's underwear.

The victim was fourteen years old and visibly pregnant at the time of trial, two years after the date of the alleged sexual assault. She testified that she was pregnant by a man other than the defendant and that at the time of the alleged sexual assault was having sexual relations with yet another adult male. As it progressed, the jury trial revolved around the testimony of the State's and the defense's DNA experts. The prosecution made its case based on the testimony given by the alleged victim and DNA evidence tested by the State's crime laboratory. The prosecution asserted that the samples obtained from the underwear of the alleged victim contained the DNA of only the victim and the accused, thereby proving beyond a reasonable doubt that the accused sexually assaulted the alleged victim. The defense countered that the DNA analysis made on these same samples by the State's crime laboratory was deficient in that the samples revealed the DNA of three individuals, and therefore the DNA evidence alone was insufficient to meet the State's burden of proving guilt beyond a reasonable doubt, the highest burden of proof in the law.

The State's expert testified on cross-examination that "because the semen stain was a 'mixture sample,' the probability was not high enough to say 'within a reasonable degree of scientific certainty' that the accused defendant was the source" [5]. Similarly, our forensic expert explained that when multiple contributors have similar alleles, it is difficult to establish clear DNA profiles [5]. The respective testimony also explained the laboratory analysis of the key DNA evidence in relation to the victim's physical examination and other evidence. The sexual assault evidence kit derives the primary samples for assessment from an extensive physical examination, whereby the underclothing and other testing procedures are performed for a DNA analysis investigation [6]. More than two days after the victim's sexual encounter, the SANE nurse assured the mother and the victim that evidence can be collected up to ninety-six hours after the incident even with bathing and changing of clothes and yield a viable result. Within laboratories and forensic testing sites "most facilities collect specimens only if the child is seen within the first 72 hours following the assault", and "many facilities process the forensic kits hours or even days after evaluation" [7].

\section{Materials \& Methods}

\section{Sample Collection, DNA Extraction, PCR, and STR Analysis Samples}

Following samples were collected: (Item I) Panties from the victim. (Item II) Sexual Assault kit from the victim consisting of: (IIa) known blood sample, (IIbi) vaginal swabs (6), (IIbii) vaginal smear (1), (IIci) anal swabs (4), (IIcii) anal smear (1), (IIdi) left ear swabs (2), (IIdii) right ear swabs (2). (Item III) Known blood sample from the suspect.

\section{Body fluid Identification Schemes for Blood and Semen ${ }^{1}$}

DNA Extraction: The stain from the undergarment was extracted by a two step method. This method first recovers DNA from nonsperm cells associated with the victim, known as the epithelial cell fraction. Then a differential assay recovers DNA from sperm cells, also called the sperm cell fraction [8]. DNA was amplified by using Polymerase Chain Reaction (PCR) procedures [9]. This technique amplifies very small amounts of evidential DNA [10]. STR's were then identified from 13 or 16 loci across the human genome for comparing the profiles of the suspect DNA with the sample DNA as according to the probability of their occurrence in the population. A portion of the known blood samples were analyzed by extracting DNA from them

A typical analysis scheme for a bloodstain follows. Note that appropriate outcome is indicated in bold italics.

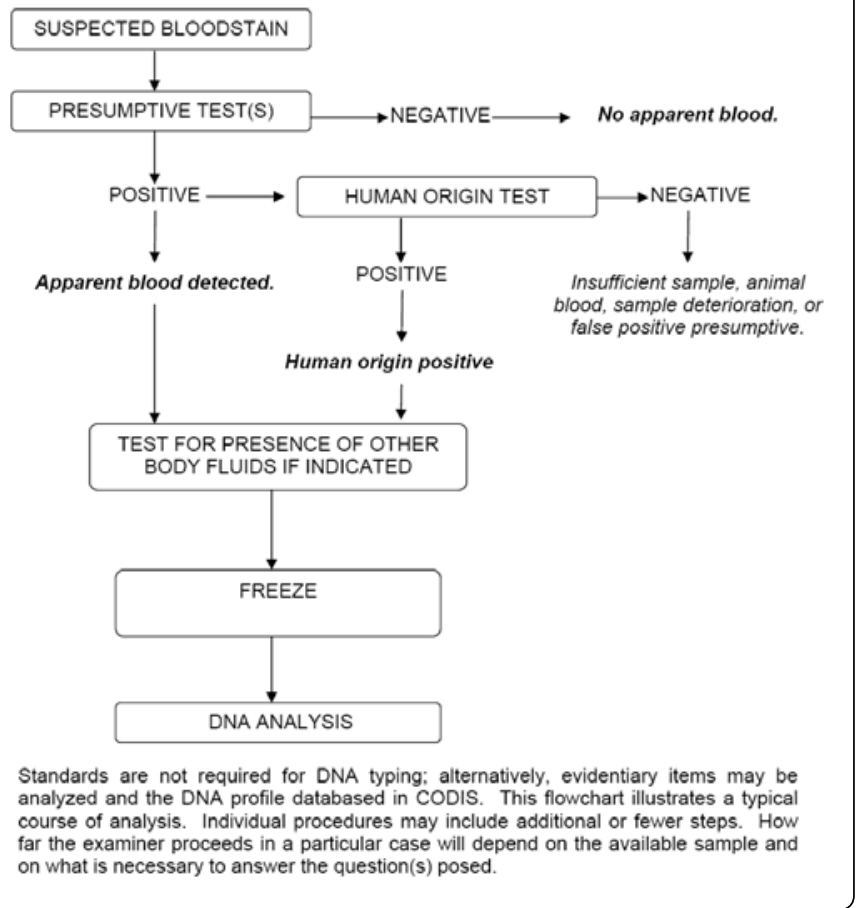


A typical analysis scheme for a suspected semen stain or swab is as indicated below Note that appropriate outcome is indicated in bold italics

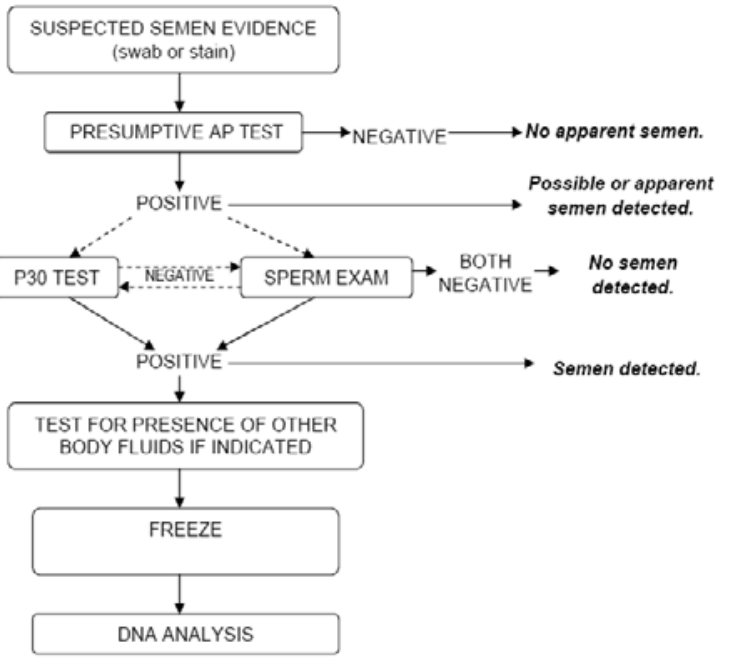

The positive amplification control tests for proper amplification of samples, as well as ensuring that GeneMapper $10^{T M}$ is working properly. A positive amplification control is included in Identifiler Thu amplification kits. This control must exhibit the following typing
results:

Identifiler ${ }^{\mathrm{TM}}$

\begin{tabular}{|l|l|l|l|l|l|l|l|l|}
\hline D8S1179 & D21S11 & D7S820 & CSF1PO & D3S1358 & TH01 & D13S317 & D16S539 & D2S1338 \\
\hline
\end{tabular}

\begin{tabular}{|l|l|l|l|l|l|l|l|l|}
\hline 13,13 & 30,30 & 10,11 & 10,12 & 14,15 & 8,93 & 11,11 & 11,12 & 19,23 \\
\hline
\end{tabular}

\begin{tabular}{|l|l|l|l|l|l|l|} 
D19S433 & WWA & TPOX & D18S51 & Amel & D5S818 & FGA \\
\hline
\end{tabular}

\begin{tabular}{|l|l|l|l|l|l|l|}
\hline 14,15 & 17,18 & 8,8 & 15,19 & $\mathrm{X}, \mathrm{X}$ & 11,11 & 23,24 \\
\hline
\end{tabular}

using the Chelex method. This DNA was amplified in loci of interests by the polymerase chain reaction (PCR).

DNA Typing: Then the following DNA STR loci were characterized. D8S1179, D21S11, D7S820, CSF1PO, D3S1358, TH01, D13S317, D16S539, D2S1338, D19S433, vWA, TPOX, D18S51, D5S818, FGA, and the sexing locus Ameleogenin.

The same loci are typed for a positive amplification control as given in an example protocol below ${ }^{2}$ :

Thus these alleles located on the above specific loci were analyzed at sixteen locations of the human genome [11]. This information was used to find the marker profile for the specific sample's genetic makeup [12].

An Applied Biosystems Genetic Analyzer ABI 310 was utilized for DNA fragment analysis (Short Tandem Repeats). The resulting electropherogram was then examined by the software program Genemapper ID v.3.2.1. Genemapper $\mathrm{ID}^{\mathrm{m}}$ is an automated genotyping software used for analysis of data collected on a capillary electrophoresis instrument such as the ABI 310 Genetic Analyzer. Processed with resolution of parameters set, the Genemapper ID analyses frequencies of peak area values accompanying the allelic band designation [13]. The DNA profile obtained from the suspect was compared to DNA profiles obtained from the stains from victim's panties. Technicians compared known DNA profiles from blood sample specimens collected from the suspect and the victim, to those from swab samples obtained from the undergarment submitted for evidence [4]. The alleged suspects' DNA profile information was also sent to the Combined DNA Index System (CODIS).

\section{Results}

\section{Presumptive tests}

Item I (panties): Trace amount of blood detected. Semen was detected. A stain marked A was collected for DNA typing. No hairs were observed.

(Item Ila) known blood sample-Victim: DNA extracted and DNA profile obtained.

(IIbi) vaginal swabs (6): No apparent blood or semen detected.

(IIbii) vaginal smear (1): No semen detected.

(IIci) anal swabs (4): No apparent blood or semen detected.

(IIcii) anal smear (1): No semen detected.

(IIdi) left ear swabs (2): No apparent blood or semen detected. Amylase a non-specific enzyme found in saliva was not detected.

(IIdii) right ear swabs (2): No apparent blood or semen detected. Amylase a non-specific enzyme found in saliva was not detected.

(Item III) known blood sample-Suspect: DNA extracted and DNA profile obtained.

\section{DNA typing}

Results showed the DNA STR fragment profile from the epithelial cell fraction on Item I Stain A (panties) is consistent with a mixture. When considering the known DNA profile of the victim, the victim could not be excluded as a contributor to this stain. The suspect could not be excluded either. The DNA profile from the sperm cell fraction of the semen stain on Item 1 Stain A (panties) is consistent with a mixture. The victim could not be excluded as a contributor to this stain. The suspect could not be excluded either. The probability of selecting an unrelated person from the suspect at random who could be a contributor to this stain was approximately 1 in the seventy odd millions for Caucasians, 1 in two and a half billion for Blacks, and 1 in one a hundred odd million for Hispanics.

\section{Discussion}

The results from DNA typing comparing known DNA sample from the victim blood (Item Ila) with that of stain A obtained from her panties (Item I) showed that this stain contained her DNA. When comparing the known DNA from the suspect with this stain A obtained from the victims panties (Item I) showed that his semen was found therein. However, DNA typing showed that the DNA of another person was also found in this mixture sample making the identification more complicated. Since neither the victim nor the suspect carried an allele number 14 seen at locus D8S1179 (Figure

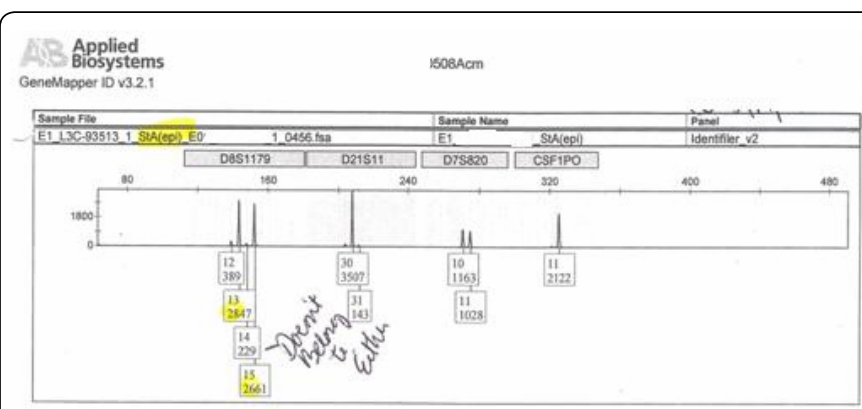

Figure 2: Electropherogram of mixed samples that show alleles from a third contributor. 
2), the differentiated and separated evidence using PCR procedures suggests that a third person's DNA was also present within the unknown sample from the victim's panties as seen in Table 1 .

Peak detection on a particular site of the allele must be approximately 100 - 150 Relative frequency Units (RFU) to be a reliable declaration of an individual's allele, due to misleading static factors found within the systems' analysis that may disqualify as unreliable peak heights.

The observation of RFU values produced through STR analysis, sometimes show comparatively low peaks within frequency and amplification standards of the alleles present on certain loci within the individual samples tested. However, the observed peak for the unknown allele was well above the minimum, with an RFU over 1,800 units. These tests are performed to reveal the separated amplified DNA fragment distributions of alleles within an individual's DNA and provide fragment size comparisons [14]. Within the human genome there are 3 billion bases, but it is only $0.1 \%$ of its makeup that is unique to an individual [12] which is used for DNA typing for forensic purposes.

In another similar sexual assault case reported by Thompson JD, Ph.D., [3] a second man who was supposedly excluded as a possible source of semen by the crime lab. However, a review of the electronic data by the defense expert revealed low RFU level peaks and alleles consistent with a second contributor. In the defense evaluation of electrophoresis data (Figure 3) how these low-level peaks are obscured by the upper electropherogram (with RFUs in the maximum range of 1800 -2000). However, when the electronic data (Genemapper ID application file) was amplified on the $Y$ axis by the defense expert ( 0 $-150 \mathrm{RFU})$, several other alleles at $12,13,16 ; 32.2 ; 14$, were depicted. In this particular case the defendant admitted being with the victim, but contended that the other second man had subsequently raped her. This data was consistent with the DNA profile the second man, which had helped the defense case significantly [3].

The analysis from the subject case in this article also revealed

\begin{tabular}{|l|l|}
\hline Evidence Tested & $\begin{array}{l}\text { Identifying Matching } \\
\text { Alleles }\end{array}$ \\
\hline Victim & 13,15 \\
\hline Suspect \#1 & 12,13 \\
\hline 1 Stain Epithelial: Panties (inside crotch) & $12,13,14,15$ \\
\hline 1 Stain Sperm: Panties (inside crotch) & $12,13,15$ \\
\hline
\end{tabular}

Table 1: Excerpt Allele Summary Worksheet.

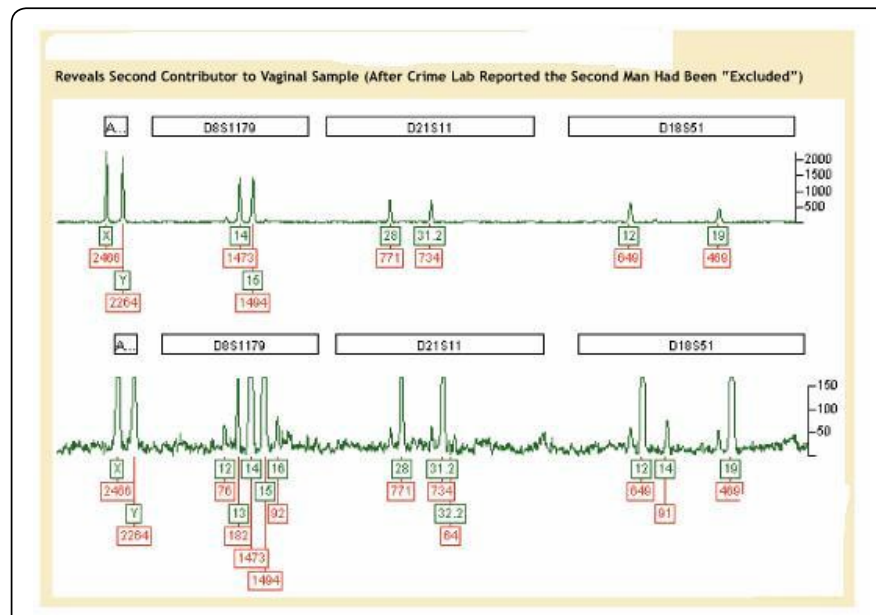

Figure 3: Defense Evaluation of Electrophoresis Data. contributions from the victim, the defendant, and a third contributor. The electronic data was limited from being presented to the jury, and further processing was not possible. Therefore, although an element of reasonable doubt was raised regarding the mixed DNA sample presented at trial by our defense DNA expert; when he testified that a third contributor "could lower the reliability of the results obtained from one sample", the jury found the defendant guilty of aggravated sexual assault [5]. The suspect received a life sentence.

On appeal the appellate court affirmed defendant's conviction, holding that the trial court did not abuse its discretion in limiting expert testimony. In reviewing the sufficiency of evidence to support a conviction, the court cited Ellison v State, 201 SW 3d 714 (Crim. App. 2006), concluding that although expert testimony is admissible to assist a jury to understand esoteric or technical information in relation to other evidence, the jury's evaluation of the evidence and its decision based on that evidence, will not be disturbed on appeal [15].

In conclusion this case demonstrates that a victim's testimony standing alone, without any forensic testimony whatsoever, supports a conviction of a defendant Garcia v State, 563 SW 2d 925 (Crim. App. 1978) [16]. It is therefore imperative that the forensic scientist be ever mindful that the legal system will always defer to a jury's decision. Despite the most diligent analysis of DNA samples in the laboratory before trial, or the most articulate argument for or against such analysis at trial, it is presumed that twelve members of the public will best weigh the credibility of evidence as it is presented.

\section{References}

1. Budowle B, Moretti TR, Niezgoda SJ, Brown BL (1998) Proceedings of the Second European Symposium on Human Identification. Madison Wisconsin Promega Corporation 73-88.

2. Chakraborty R, Stivers DN, Su Y, Budowle B (1999) Electrophoresis. 20: 1682 1696.

3. Thompson WC, Ford S, Doom T, Raymer M, Krane DE (2003) The Champion Magazine. National Association of Criminal Defense Lawyers 16.

4. Lerner EKL, Lerner BW (2005) Technology and Forensic Science. World of Forensic Science.

5. Court of Appeals of Texas, Corpus Christi-Edinburg (2010) Memorandum Opinion (Not Reported) No 13-09-00037-CR Thomson Reuters

6. Linden JA (2005) Sexual Assault. Emerg Med Clin North Am 17: 685-697.

7. Muram D (2001) The Medical Evaluation in Cases of Child Sexual Abuse Mini-Review. North American Society for Pediatric and Adolescent Gynecology Elsevier14: 55-64.

8. Kanako Y, Sekiguchi K, Mizuno N, Kasai K, Sakai I, et al. (2000) The modified method of two-step differential extraction of sperm and vaginal epithelial cell DNA from vaginal fluid mixed with semen. Forensic Sci Int 72: 25-33.

9. Swango KL, Timken MD, Chong MD, Buoncistiani MR (2006) A quantitative PCR assay for the assessment of DNA degredation in forensic samples. Forensic Sci Int 158: 14-26.

10. Lerner EKL, Lerner BW (2005) DNA Profiling World of Forensic Science Gale Detroit Gale Virtual Library.

11. Gingras F, Paquet C, Bazinet M, Granger D, Marcoux-Legault K (2009) Biological and DNA evidence in 1000 sexual assault cases. Forensic Science International: Genetics Supplemental Series 2: 138-140.

12. Lerner EKL, Lerner BW (2005) DNA Typing Systems. World of Forensic Science.

13. Clayton TM, Whitaker JP, Sparkes R, Gill P (1998) Analysis and interpretation of mixed forensic stains using DNA STR profiling. Forensic Sci Int 91: 55-70.

14. Ayn-Seddon E, Pass AD (2009) DNA Typing. Forensic Science Vol. 2: Pasadena, CA: Salem Press.

15. Court of Criminal Appeals of Texas (2006) Larry Martin Ellison v The State of Texas. No PD-0863-05 201 SW3d 714 Thomson Reuters.

16. Court of Criminal Appeals of Texas (1978) Guadalupe Garcia v The State of Texas. No 54179563 SW2d 925 Thomson Reuters. 